\title{
Pelatihan Teknis dalam Rangka Perbaikan Mutu Gula Semut di Kabupaten Tasikamaya
}

\section{(Brown Sugar Quality Improvement through Technical Training in Tasikmalaya District)}

\author{
Tjahja Muhandri ${ }^{1,2^{*}}$, Didik M Rifqi ${ }^{3}$, Tutik Lestari ${ }^{4}$,Slamet Widodo ${ }^{5}$ \\ 1 Departemen Ilmu dan Teknologi Pangan, Fakultas Teknologi Pertanian, Institut Pertanian Bogor, \\ Kampus IPB Darmaga, Bogor 16680. \\ 2 Seafast Center, Institut Pertanian Bogor, Kampus IPB Darmaga, Bogor 16680. \\ 3 Unit Laboratorium Pengujian Kalibrasi dan Sertifikasi, Institut Pertanian Bogor, Kampus IPB Darmaga, Bogor 16680. \\ 4 PT IZ Raya Pratama, Griya Bukit Blok L6 no. 11, Bojong Nangka, Gunung Putri, Bogor 16963 \\ 5 Departemen Teknik Pertanian dan Biosistem, Fakultas Teknologi Pertanian, Institut Pertanian Bogor, \\ Kampus IPB Darmaga, Bogor 16680. \\ Penulis Korespodensi: cahyomuhandri@yahoo.com \\ Diterima November 2019/Disetujui Agustus 2020
}

\begin{abstract}
ABSTRAK
Usaha Kecil dan Menengah (UKM) di Kabupaten Tasikmalaya masih dikelola secara tradisional. UKM belum menerapkan standar proses sehingga produk akhir memiliki mutu yang beragam. Kegiatan ini bertujuan untuk memberikan pelatihan tentang jaminan mutu gula semut, Cara Produksi Pangan Olahan yang Baik (CPPOB), sanitasi serta praktik pembuatan gula semut yang baik dan penggunaan alat-alat ukur untuk standarisasi proses. Kegiatan pelatihan dilakukan selama 5 hari di Kecamatan Sariwangi, Kabupaten Tasikamalaya dengan peserta 20 pelaku usaha gula semut dari 4 kecamatan, yaitu Sariwangi, Culamega, Puspahiang, dan Curug Gambir. Hasil kegiatan menunjukkan bahwa semua peserta belum memiliki sarana produksi yang memenuhi syarat CPPOB, belum memahami makna jaminan mutu serta penggunaan alat-alat ukur yang mendukung perbaikan mutu gula semut. Hasil post-test menunjukkan adanya peningkatan kesadaran UKM tentang jaminan mutu gula semut yang ditunjukkan dengan kenaikan skor tes dari 31,39 menjadi 49,72. Perbaikan proses yang dilakukan meliputi perbaikan penyaringan nira, kristalisasi, dan penambahan putih telur untuk mengikat kotoran. Mutu produk pascapelatihan meningkat, terutama dari aspek kebersihan dan warna yang lebih cerah.
\end{abstract}

Kata kunci: gula semut, pelatihan, perbaikan mutu, UKM

\begin{abstract}
Small and Medium Enterprises (SME's) in Tasikmalaya District are still managed traditionally. SME's has not implemented a standard process so that the final product has various qualities. This activity aims to provide training on brown sugar quality assurance, Good Manufacturing Processes (GMP), sanitation, as well as good practice of brown sugar making and the use of measuring tools to standardize the process. The training was carried out for five days in Sariwangi District, Tasikmalaya Regency with the target of 20 sugar entrepreneurs from 4 districts, namely Sariwangi, Culamega, Puspahiang, and Curug Gambir. The results showed that all participants did not yet have production facilities that met the GMP requirements, did not understand the meaning of quality assurance and the use of measuring instruments that supported the improvement of the quality of brown sugar. The post-test results showed an increase in the awareness of SMEs about quality assurance of brown sugar, as indicated by the rise in the test score from 31.39 to 49.72 . Process improvements include improving the sap filtering, crystallization, and adding egg white to bind the impurities. The quality of post-training products has improved, especially in terms of cleanliness and brighter colors.
\end{abstract}

Keywords: brown sugar, SME's, training, quality improvement

\section{PENDAHULUAN}

Produk gula semut dibuat oleh para pengusaha kecil menggunakan cara yang masih tradisional. Permasalahan yang dihadapi adalah mutu yang tidak baik antara lain produk yang kotor, kadar air tinggi (Lay \& Karouw 2011), warna gelap dan tidak seragam. Gula semut dengan mutu yang kurang bagus akan memiliki keterbatasan dalam meraih pasar yang lebih modern. Gula semut yang beredar di pasaran memiliki warna yang gelap (cokelat tua). Putra 
(2016) menyatakan bahwa penambahan Natrium Metabisufit sebanyak 200 ppm mampu memperbaiki kecerahan gula semut. Penyebab warna gelap adalah pemanasan yang berlebih sehingga proses karamelisasi terjadi pada gula semut (Putra 2016).

Sebagian besar UKM gula semut aren belum memiliki spesifikasi yang jelas dari bahan baku yang digunakan dan belum memiliki standar proses (Instruksi Kerja). Seluruh aspek terkait bahan baku dan produksi dikelola dengan cara tradisional. UKM tidak mampu memberikan jaminan mutu kepada konsumen untuk produk yang dihasilkannya. UKM perlu menerapkan sistem jaminan mutu untuk meningkatkan kemampuan dalam persaingan (Karipidis et al. 2009). Sistem jaminan mutu untuk UKM harus dimulai dari penyusunan spesifikasi bahan dan produk serta penyusunan Instruksi Kerja proses produksi. PP no 28 tahun 2004 menyebutkan bahwa seluruh sistem jaminan mutu yang diterapkan di industri pangan memerlukan persyaratan dasar berupa Cara Produksi Pangan Olahan yang Baik (CPPOB).

BPOM menyampaikan data bahwa pada tahun 2017, baru 10,97\% dari 2.352 IRTP (Industri Rumah Tangga Pangan), yang sudah melakukan СРРОВ (Nurcahyo 2018). Muhandri et al. (2016) menyebutkan bahwa 24 UKM pangan yang menjadi sampel di Kota Palu, Sulawesi Tengah, semuanya belum menerapkan CPPOB dengan sempurna. Belum semua UKM Gula Semut di Kabupaten Tasikmalaya memiliki ijin edar PIRT. Persyaratan utama dalam pengajuan PIRT adalah telah mengikuti pelatihan CPPOB.

Permasalahan lain yang dihadapi dalam industri gula semut di Kabupaten Tasikmalaya adalah ketidakseragaman mutu produk gula semut, terutama pada aspek warna dan kadar air yang masih di atas standar pemerintah. Peserta belum memiliki sarana alat ukur, terutama alat ukur kadar air dan kadar gula, serta belum memahami cara pemakaian alat ukur tersebut

Kegiatan pelatihan teknis untuk UKM Gula Semut dari aren di Kabupaten Tasikmalaya mencakup aspek CPPOB, penyusunan spesifikasi dan instruksi kerja, perbaikan teknis produksi gula semut, serta penggunaan peralatan pengukuran pH, kadar air dan kadar gula (Brix). Kegiatan pelatihan meliputi teori dan praktik pembuatan gula semut yang benar. Hasil yang diharapkan adalah peningkatan kemampuan pemahaman peserta dan perbaikan mutu produk gula semut yang dihasilkan.

\section{METODE PELAKSANAAN KEGIATAN}

\section{Waktu, Tempat dan Peserta Pelatihan Perbaikan Mutu Gula Semut}

Kegiatan pelatihan dilaksanakan di Desa Sukaharja, Kecamatan Sariwangi, Kabupaten Tasikamalaya. Pelatihan dilakukan selama 5 hari, mulai tanggal 28 Oktober-1 Nopember 2019. Kegiatan pelatihan diikuti oleh 20 UKM Gula Semut yang berasal dari 4 kecamatan di Kabupaten Tasikmalaya, yaitu Kecamatan Sariwangi, Culamega, Puspahiang dan Curug Gambir.

\section{Penilaian Peningkatan Pemahaman Peserta terhadap Materi Pelatihan}

Peserta diberikan kuesioner yang berisi 20 pertanyaan tentang aspek CРPOB (7 pertanyaan), jaminan mutu (7 pertanyaan) dan aspek teknis produksi gula semut (6 pertanyaan). Peserta diminta mengisi sebelum pelatihan (pre test) dan sesudah pelatihan dilaksanakan (post test). Nilai maksimum yang dapat diperoleh adalah 100. Nilai yang diperoleh peserta merupakan indikator peningkatan pemahaman terhadap materi yang diberikan.

\section{Pemberian Materi Pelatihan}

Pelatihan teori diberikan pada hari pertama dan kedua. Materi meliputi CPPOB, higiene dan sanitasi, kemasan, pemasaran, jaminan mutu, aspek teknis dalam pembuatan gula semut serta penggunaan alat-alat ukur dalam proses produksi. Pelatihan praktik diberikan pada hari ketiga dan keempat. Praktik meliputi pembuatan gula semut yang benar, dan penggunaan alat-alat ukur. Hari kelima diisi dengan evaluasi terhadap mutu produk sebelum pelatihan (produk berasal dari peserta) dan sesudah pelatihan (produk yang dihasilkan pada saat praktik).

\section{HASIL DAN PEMBAHASAN}

\section{Peningkatan Pemahaman Peserta terhadap Materi Pelatihan}

Kemampuan peserta mengalami peningkatan setelah mengikuti pelatihan. Nilai rata-rata hasil pre test peserta adalah 31,39 (dari nilai maksimum 100) dan hanya ada 1 peserta yang memperoleh nilai di atas 50. Lyimo (2017) menyatakan bahwa 92,2\% pelaku industri kecil di Turki dan 40\% pelaku industri kecil dan menengah di Inggris tidak mengetahui tentang Good Manufacturing Practices (GMP). 
Pemberian materi meningkatkan pemahaman peserta, yang dibuktikan dengan hasil post test rata-rata sebesar 54,17 dan ada 8 peserta yang mendapatkan dilai di atas 50. Peningkatan pemahaman peserta setelah pemberian materi teori dan praktik terjadi pada semua aspek yang dilatihkan ( $\mathrm{CPPOB}$, teknologi proses, kemasan dan label, manajemen serta dokumentasi). Hal ini senada dengan pernyataan Singh et al. (2018), bahwa pemahaman karyawan terhadap GMP meningkat setelah dilakukan pelatihan selama dua hari.

Peningkatan tertinggi pada aspek teknologi, yaitu dari 29,12 menjadi 62,50. Pemahaman peserta terhadap aspek kemasan dan label tidak berubah, yaitu sebesar 25,93. Hal ini karena peserta menganggap bahwa desain dan pencetakan label diserahkan pada jasa percetakan, sehingga jasa percetakan yang harus lebih memahami aturan tentang label.

\section{Pemberian Materi Teori}

Pelatihan dilaksanakan di dalam kelas. Materi teori meliputi cara pembuatan gula semut yang baik dan penggunaan alat-alat ukur ( $\mathrm{pH}$ meter, moisture tester dan hand refactometer). Materi disampaikan searah dan dilanjutkan dengan diskusi. Peserta antusias mengikuti pelatihan yang ditunjukkan dengan banyaknya pertanyaan yang disampaikan pada saat diskusi. Suasana pemberian materi dapat diihat pada Gambar 1.

Alat pH meter digunakan untuk mengukur nilai $\mathrm{pH}$ suatu larutan. Gula semut sulit menjadi kristal jika nira yang digunakan memiliki $\mathrm{pH}$ di bawah 6,5. Setiap peserta diminta untuk praktik menggunakan $\mathrm{pH}$ meter supaya paham nilai $\mathrm{pH}$ dari nira yang mereka gunakan untuk membuat gula semut. Kondisi asam ( $\mathrm{pH}$ rendah) dapat menyebabkan reaksi inversi sukrosa. Menurut Zuliana et al. (2016) reaksi inversi sukrosa dipengaruhi oleh sifat asam, substrat, suhu lingkungan, kebersihan lingkungan, dan keberadaan

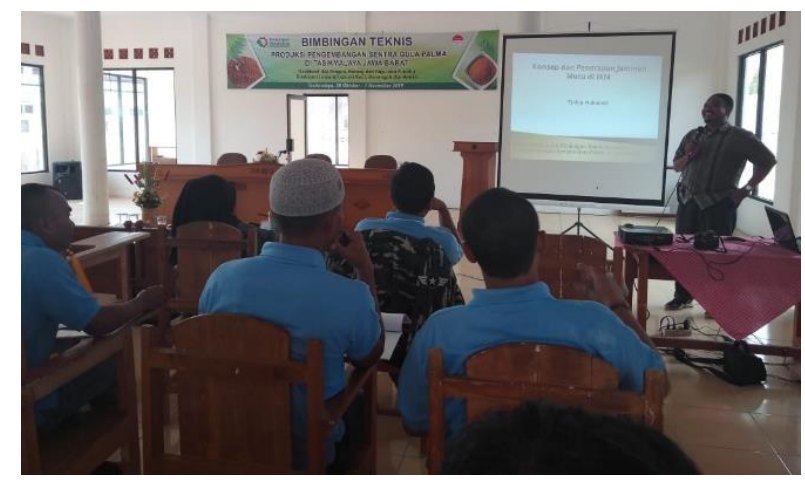

Gambar 1 Pemberian materi teori. enzim intervase Gula invert atau gula pereduksi tidak dapat berbentuk kristal karena glukosa dan fruktosa memiliki kelarutan yang cukup tinggi. Moisture tester digunakan untuk mengukur kadar air gula semut yang dihasilkan. UKM diajarkan teori dan praktik penggunaan alat ini supaya dapat mengukur kadar air produknya.

Nira yang diambil dari pohon aren memiliki nilai total padatan terlarut yang rendah, sehingga tidak bisa disimpan dalam waktu yang lama. Nira segar hanya mampu bertahan selama 3 jam disimpan di suhu ruang (Atmoko 2017). Seringkali jumlah nira yang diperoleh oleh tiap UKM terlalu sedikit untuk diproses langsung menjadi gula semut. UKM perlu memiliki sediaan nira kental yang awet disimpan pada suhu ruang, sehingga proses kristalisasi gula aren dapat dilakukan pada jumlah yang optimum. Nira yang memiliki total padatan terlarut di atas 65 Brix, dapat disimpan pada suhu ruang.

\section{Praktik Pembuatan Gula Semut}

Peserta pelatihan dibagi menjadi 4 kelompok sesuai dengan kecamatan masing-masing, setiap kelompok membuat gula semut dengan bahan nira sebanyak 10 L. Setiap kelompok membuat gula semut dengan teknik yang telah dimiliki sebelumnya, tetapi diberikan tambahan perlakuan dalam rangka peningkatan mutu produk.

Perbaikan proses yang dilakukan adalah 1) Penyaringan nira menggunakan saringan 100 mesh; 2) Pengambilan kotoran dengan penyiruk berlubang kecil (100 mesh) selama proses pemasakan; 3) Pengurangan jumlah nira yang dimasak; 4) Penggunaan putih telur untuk mengikat kotoran berukuran kecil; dan 5) Penggunaan oven pengering untuk menurunkan kadar air gula semut.

Pada pelatihan ini, pemasakan gula semut masih menggunakan kayu bakar sesuai dengan kondisi riil di masyarakat. Suasana praktik disajikan pada Gambar 2. Gula semut hasil praktik

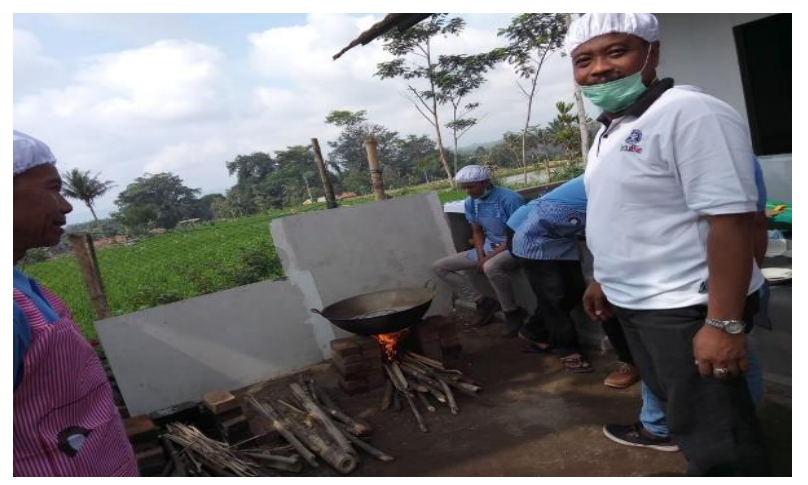

Gambar 2 Praktik pembuatan gula semut. 
terbukti memiliki mutu yang jauh lebih bagus dibandingkan dengan gula semut yang dibawa oleh kelompok (gula semut produksi rutin kelompok). Terlihat pada Gambar 3 bahwa gula semut hasil praktik memiliki warna yang jauh lebih cerah, penampakan lebih bersih, dan kadar air yang lebih rendah.

Perbaikan warna gula semut aren tidak perlu menggunakan bahan kimia seperti yang disebutkan oleh Putra (2016). Jumlah optimum dari nira aren yang dimasak, mencegah adanya pemanasan berlebih, karamelisasi gula optimum, dan warna gula semut aren menjadi jauh lebih cerah (Gambar 3c). Penambahan putih telur mampu mengikat kotoran berukuran kecil dan menghasilkan sirup gula yang lebih jernih serta warna yang lebih muda (Zarlis 2010).

Kadar air gula semut yang dibawa oleh kelompok berkisar antara 10-13\%, sedangkan hasil pelatihan memiliki kadar air 3\% (sesuai SNI gula semut). Hal ini terjadi karena sebagian besar UKM masih mengeringkan gula semut dengan menjemur, sehingga sulit untuk menurunkan kadar air sampai d ibawah $10 \%$.

Warna contoh gula semut yang dibawa oleh kelompok peserta (Gambar 3a dan b) memiliki warna yang cokelat gelap karena proses kristalisasi gula dilakukan dalam jumlah yang besar.
Proses kristalisasi berjalan lambat, gula semut mengalami kelebihan pemanasan sehingga gula semut mengalami karamelisasi yang berlebih. Perbaikan warna gula semut menjadi lebih cerah dilakukan dengan penambahan gula pasir. Joseph \& Layuk (2012) menyatakan bahwa warna gula semut paling muda diperoleh pada penambahan gula pasir 20\% (dari berat gula cetak aren) yang kemudian dikristalkan lagi.

Perbaikan proses dilakukan dengan membuat sediaan nira kental. Nira kental dibuat dengan memasak nira aren segar sampai kadar gula $25^{\circ}$ Brix (disebut wedang oleh masyarakat). Pengawetan dengan penurunan aktivitas air (peningkatan kadar gula) lebih efektif dengan pemberian bahan tambahan. Fitriyani et al. (2014) menyebutkan bahwa penambahan daun manggis dalam upaya memperpanjang umur simpan nira, terbukti tidak efektif.

Proses kritalisasi yang direkomendasikan adalah dengan pemasakan wedang (nira kental) dilakukan dalam jumlah sedikit (10-15 L) sehingga penanganan kristalisasi dapat dilakukan dengan optimum. Warna gula semut dari nira aren lebih cerah karena karamelisasi berlebih dapat dicegah. Perbaikan proses dalam pembuatan gula semut aren disajikan pada Tabel 1 .

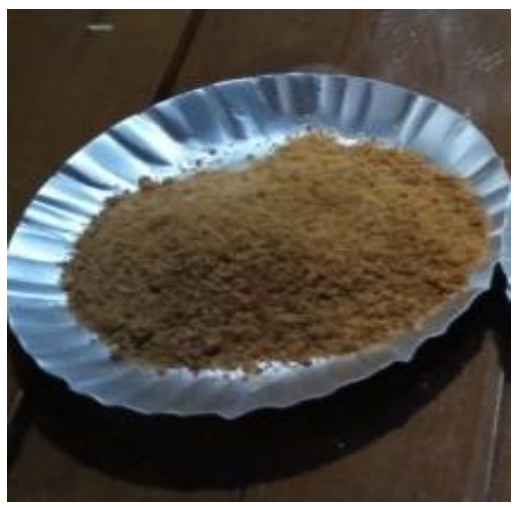

a

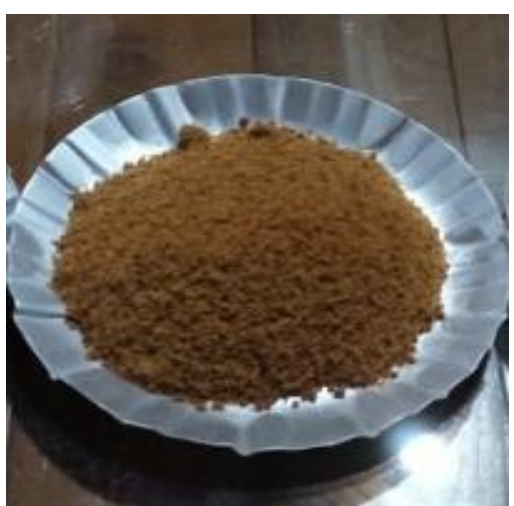

$\mathrm{b}$

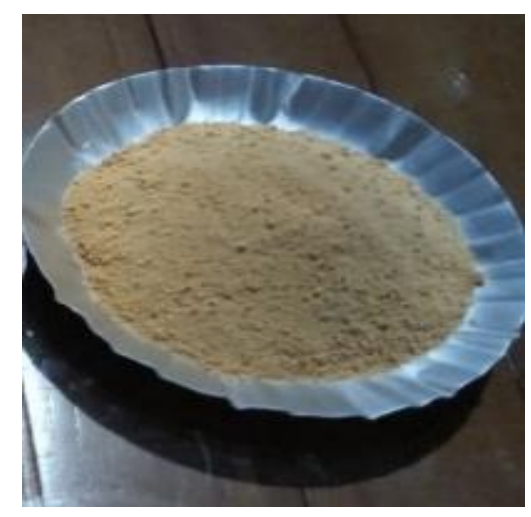

C

Gambar 3 Gula semut contoh produksi UKM peserta (a dan b), serta gula semut hasil pelatihan (c).

Tabel 1 Perbaikan proses pembuatan gula semut

\begin{tabular}{|c|c|}
\hline \multicolumn{2}{|c|}{ Aspek proses yang diperbaiki } \\
\hline Kondisi sebelum perbaikan & Kondisi sesudah perbaikan \\
\hline $\begin{array}{l}\text { Nira disaring dengan ukuran } 20 \text { mesh atau kain } \\
\text { Jumlah nira yang dimasak } 30-40 \mathrm{~L}\end{array}$ & $\begin{array}{l}\text { Nira disaring dengan ukuran } 100 \text { mesh } \\
\text { Jumlah nira yang dimasak } 10-15 \mathrm{~L}\end{array}$ \\
\hline $\begin{array}{l}\text { Tidak digunakan bahan pengikat kotoran, ketika nira } \\
\text { dimasak }\end{array}$ & Penggunaan putih telur untuk mengikat kotoran \\
\hline Nira yang sedang dimasak, tidak disaring & $\begin{array}{l}\text { Pengambilan kotoran dan telur yang menggumpal, } \\
\text { dengan saringan } 100 \text { mesh }\end{array}$ \\
\hline Pengeringan dengan matahari (penjemuran) & Pengeringan menggunakan alat pengering \\
\hline
\end{tabular}




\section{SIMPULAN}

Pemahaman peserta pelatihan meningkat dengan adanya pelatihan teknis pembuatan gula semut. Hasil tes menunjukkan peningkatan dari nilai rata-rata sebesar 31,39 (pre test) menjadi 49,72 (post test). Perbaikan proses dalam pembuatan gula semut mampu meningkatkan mutu gula semut dari aspek kecerahan warna, kadar air, dan kebersihan produk. Peserta juga memiliki kemampuan baru dalam menggunakan alat-alat pengukuran $\mathrm{pH}$, kadar air, dan kadar gula (Brix). Perbaikan proses yang dilakukan adalah 1) Standarisasi jumlah nira sebesar 10-15 L, 2) Penambahan putih telur (dari 1 butir) pada saat nira sudah mendidih; 3) Penyaringan kotoran pada nira sudah mendidih dengan saringan 100 mesh; 4) pengeringan menggunakan tray dryer.

\section{DAFTAR PUSTAKA}

Atmoko AD. 2017. Analisa pengembangan produk gula aren di Kabupaten Purworejo. Jurnal Dinamika Sosial Ekonomi. 6(1):15-28. https://doi.org/10.20961/sepa.v15i1.25046

Dewan Standarisasi Nasional. 1995. SNI: Gula Kelapa Krital SII 0268-85. Jakarta (ID): Dewan Standarisasi Nasional.

Fitriyani, Djangi MJ, Alimin. 2014. Pengaruh penambahan daun manggis hutan (Garcinia hombroniana pierre) terhadap umur simpan nira aren (Arenga pPinnata Merr). Jurnal Chemica. 15(1): 82-93.

Joseph GH, Layuk P. 2012. Pengolahan Gula Semut dari Aren. Buletin Palma. 13(1): 60-65.

Karipidis P, Athanassiadis K, Aggelopoulos S, Giompliakis E. 2009. Factors affecting the adoption of quality assurance systems in small food enterprises. Food Control. 20(2): 93-98. https://doi.org/10.1016/j.foodcont.2008.02. 008
Lay A, Karouw S. 2005. Nira aren dan teknik pengendalian produk olahan. Buletin Palma. (31): 116-125.

Lyimo JM. 2017. Good manufacturing practices compliance: the case of registered small scale maize milling industries in Ubungo and Kinondoni districs, Tanzania. [Disertasi]. Muhimbili University of Health and Allied Sciences, Dar es-Salaam.

Muhandri T, Herawati D, Budi FS, Nuraida L, Koswara S, Agista AZ, Sukmawati Y. 2016. Kesiapan usaha mikro kecil menengah pangan dalam oenerapan ISO 9001:2008 (studi kasus di Palu, Sulawesi Tengah). Agrokreatif Jurnal Ilmiah Pengabsian kepada Masyarakat. 2(2): 61-66. https://doi.org/10.29244/ agrokreatif.2.2.61-66

Nurcahyo E. 2018. Pengaturan dan pengawasan produk pangan olahan kemasan. Jurnal Magister Hukum Udayana. 7(3): 402-417. https://doi.org/10.24843/JMHU.2018.v07.i0 3.p10

Putra INK. 2016. Upaya Memperbaiki Warna Gula Semut dengan Pemberian Na-Metabisulfit. Jurnal Aplikasi Teknologi Pangan. 5(1): 1-5. https://doi.org/10.17728/jatp.v5i1.2

Singh GKS, Azman KAK, Hadi MAA, Jaafar Z, Affandi MMRMM. 2018. Scheduled and standardized training improved employees' knowledge on good manufacturing practices (GMP). International Journal Pharmacy and Pharmaceutical Sciences 10 (1):185-190. https://doi.org/10.22159/ijpps.2018v10i1.2 0827

Zarlis MS. 2010. Pengolahan minuman air tebu segar aman konsumsi. Warta Industri Hasil Pertanian. 27(1): 34-46.

Zuliana C, Widyastuti E, Susanto WH. 2016. Pembuatan gula semut kelapa (kajian $\mathrm{pH}$ gula kelapa dan konsentrasi natrium bikarbonat). Jurnal Pangan dan Agroindustri. 4(1): 109119. 